\section{Annual Bluegrass: Emergence of Viable Seed in Various Putting Green Sites and Soil Removal Depths}

\author{
Thomas O. Green ${ }^{1}$, Alexandra Kravchenko, \\ John N. Rogers, III, and Joseph M. Vargas, Jr.
}

AdDitional INDEX wORDs. golf course, Poa annua, renovation, weed

SUMmaRY. A major concern with many creeping bentgrass (Agrostis stolonifera) putting greens is annual bluegrass (Poa annua) invasion. The study was designed to garner data regarding the depth of soil removal needed to reduce annual bluegrass seedling emergence in a newly renovated putting green. Research was conducted in different seasons (summer and fall) to evaluate seedling emergence across five soil removal depths in four sampling sites. Cores were collected from four golf courses in southeastern Michigan, subdivided into different soil removal depths, potted in sterile soil media, and established in a growth chamber. Results suggest that excavating soil to a depth of 1.0 inch or, more prudently, to a 1.5 -inch depth could minimize annual bluegrass competition in a creeping bentgrass putting green. Annual bluegrass emergence was observed to be greatest in the upper soil depths $(0.5-1.5$ inches $)$ in both seasons, with minimal emergence $\left(<1.1\right.$ plant $\left./ 0.2 \mathrm{ft}^{2}\right)$ below the 2.0 -inch soil removal depth treatment.

A major concern with creeping bentgrass putting greens is the high incidence of annual bluegrass invasion. A genetically diverse and prolific seed producer (Beard et al., 1978; Ellis et al., 1971; Gibeault and Goetze, 1973; Law, 1981; Timm, 1965; Tutin, 1957; Wells, 1974; Youngner, 1959), annual bluegrass thrives in highly cultured turfs (Barkworth et al., 2003; Huff, 1999; La Mantia and Huff, 2011; Warwick, 1979) and can provide a high-quality putting surface. However, most golf course superintendents consider it an invasive weed and go to great lengths to control it in their greens (Vargas and Turgeon, 2004). Previous research has not only demonstrated the colonization of

Received for publication 12 Mar. 2019. Accepted for publication 15 May 2019.

Published online 2 July 2019.

Department of Plant, Soil, and Microbial Sciences, Michigan State University, East Lansing, MI 48824

We acknowledge the following for financial support of this research: the Michigan Turfgrass Foundation and Carl Schwartzkopf.

We also thank Mike Edgerton (retired), Meadowbrook Country Club; Colin Seaborg, Barton Hills Country Club; Brian Schweihofer, Franklin Hills Country Club; and Gary Thommes, Red Run Golf Club for their assistance with the project.

${ }^{1}$ Corresponding author. E-mail: greenth7@msu.edu.

This is an open access article distributed under the CC BY-NC-ND license (https://creativecommons.org/ licenses/by-nc-nd/4.0/).

https://doi.org/10.21273/HORTTECH04345-19 distinct, aggressive populations in greens (Sweeney and Danneberger, 1995, 1997), but also the profuse quantities that remain viable in the soil seed bank (Branham et al., 2004; Peachey et al., 2001). Although some studies quantified survival of buried annual bluegrass seed in crop production fields (Peachey et al., 2001), research has not been conducted on the amount of soil removal needed to reduce seed germination in putting greens. Therefore, it is critical to determine annual bluegrass seed germination rate within soils regarding renovation practices.

Recently, golf course renovations have peaked because of aging and functionally deficient components such as putting greens (Jones, 2019), and five principles usually dictate a renovation: major turf loss resulting from abiotic and biotic stress, loss of putting green resulting from collar encroachment, excessive organic matter accumulation, need for architectural design improvement, and invasion of undesirable turfgrass species affecting surface playability (Foy and Gilhuly, 2015). In the cool-season region, conversion to a desirable grass species such as a creeping bentgrass is one option, but the cost of renovation is a big factor. Partial removal of an existing root zone-a resurfacing, as it is commonly called - is an economically viable option that costs $20 \%$ of a total rebuild (White, 2006). A complete rebuild with total root zone removal may not be the best nor necessary option in most cases. For cool-season grass species, it has been suggested that only the upper 1.0 to 3.0 inches of existing root zone be removed (Whitlark and Hummel, 2018) when replacing a turfgrass variety for an improved variety by reseeding or sodding. This removal amount (1.0-3.0 inches) would not require adding more root zone material because most putting greens older than 10 years have sufficient additions of sand topdressing, making it deeper than the original construction depth (McCarty et al., 2005; Skorulski et al., 2010; Whitlark and Hummel, 2018). These frequent sand additions have buried annual bluegrass seed deep within the root-zone profile.

Superintendents are searching for ways to improve putting surfaces not only to appease customers, but also to decrease pesticide, fertilizer, and water inputs to be more environmentally friendly (Gilhuly, 2016; Jones, 2017). Therefore, a cost-effective renovation method must be identified to reduce annual bluegrass seedling emergence in a putting green. Perhaps excavating to at least a 1.0-inch depth or, more prudently, to a 1.5- to 2.0-inch depth of an existing root zone would have sufficient efficacy to minimize weed invasion when renovating with or without soil fumigants. The objective of this study was to evaluate the effects of putting green site, soil removal depth, and season on annual bluegrass seedling emergence.

\section{Materials and methods}

Observations on annual bluegrass seedling emergence were conducted in summer and fall (20 Aug. 2015 and 16 Oct. 2015) at the Michigan State University (MSU); Plant,

\begin{tabular}{llll}
\hline $\begin{array}{l}\text { Units } \\
\begin{array}{l}\text { To convert U.S. to SI, } \\
\text { multiply by }\end{array}\end{array}$ & U.S. unit & SI unit & $\begin{array}{l}\text { To convert SI to U.S., } \\
\text { multiply by }\end{array}$ \\
\hline 0.0929 & $\mathrm{ft}^{2}$ & $\mathrm{~m}^{2}$ & 10.7639 \\
2.54 & inch $(\mathrm{es})$ & $\mathrm{cm}$ & 0.3937 \\
48.8243 & $1 \mathrm{~b} / 1000 \mathrm{ft}^{2}$ & $\mathrm{~kg} \cdot \mathrm{ha}^{-1}$ & 0.0205 \\
$\left({ }^{\circ} \mathrm{F}-32\right) \div 1.8$ & ${ }^{\circ} \mathrm{F}$ & ${ }^{\circ} \mathrm{C}$ & $\left({ }^{\circ} \mathrm{C} \times 1.8\right)+32$
\end{tabular}


Soil, and Microbial Sciences Growth Chamber Facilities; East Lansing, MI. Sampling sites were four golf courses with native soil "push-up" greens (Hurdzan, 2004) located in southeastern Michigan (Table 1): Barton Hills Country Club (CC), Ann Arbor, MI; Franklin Hills CC, Franklin, MI; Meadowbrook CC, Northville, MI; and Red Run Golf Club (GC), Royal Oak, MI. The studied factor was soil removal depth of the putting green root zone $(0.5,1.0,1.5,2.0$, and 3.0 inches). During each season, 15 soil cores were removed randomly from a single putting green at each sampling site to assess annual bluegrass seed germination at different soil removal depths. A 4-inch-diameter golf cup cutter (Lever Action Hole Cutter; Par Aide, Lino Lakes, MN) was used to remove cores to a depth of 3.0 inches from the sample greens. As shown in Table 2, distinct differences among study sites may reflect both the variation in topdressing application rates because most were topdressed extensively during the past 25 years (M. Edgerton, B. Schweihofer, C. Seaborg, and G. Thommes, personal communication). Barton Hills CC had a relatively shallow sand topdressing layer based on the rationale that its silt and clay percentage increased sharply to $25.4 \%$ (indicative of a sandy-loam native layer) at the 2.0-inch soil removal depth, whereas all others were between $4 \%$ and $5 \%$.

A total of 60 cores were collected during each season. The cores were brought to the greenhouse and subjected to soil removal depth treatments. Cores from each season and each sampling site were assigned randomly to these treatments, with three cores per soil removal depth for each site and season. Soil of each core was removed to the respective depth treatment with a core-slicing apparatus (MSU Soil and Plant Nutrient Laboratory, East Lansing, MI), was an open-top wooden box ( 4.5 inches wide $\times 12$ inches long) with side slots so that a sawblade could separate soil cores precisely into depth intervals of 0.0 to $0.5,0.5$ to $1.0,1.0$ to $1.5,1.5$ to 2.0 , and 2.0 to 3.0 inches. Each soil removal depth treatment was placed intact, if possible (some sections broke apart), and level with the surface of the potting media $(55 \%$ sphagnum peatmoss with equal parts processed pine bark, perlite, and vermiculite). All treatment pots (6.5inch diameter $\times 4.5$-inch depth) were then placed into a controlled-environment growth chamber as described by Merewitz et al. (2011). Conditions were set to maintain a $500-\mu \mathrm{mol} \cdot \mathrm{m}^{-2} \cdot \mathrm{s}^{-1}$ photosynthetic photon flux density; daytime and nighttime temperatures of 78.4 and $68.0^{\circ} \mathrm{C}$, respectively; regulated at $67 \%$ relative humidity with a 14 -h photoperiod. Fertilization consisted of weekly applications of $50 \%$ Hoagland solution (Hoagland and Arnon, 1950) through mist-nozzle irrigation with $\approx 0.10$ inch of water applied during a single irrigation period. For this experiment, emerged annual bluegrass seedlings were counted

Table 1. Descriptive analysis of the sample of golf course putting greens used in the study to determine annual bluegrass emergence at different soil removal depths and sites in 2015 at East Lansing, MI. ${ }^{\mathrm{z}}$

\begin{tabular}{|c|c|c|c|c|}
\hline Site & $\begin{array}{l}\text { Annual } \\
\text { bluegrass:creeping } \\
\text { bentgrass ratio (\%) }\end{array}$ & $\begin{array}{l}\text { Putting } \\
\text { green age } \\
(\mathrm{yr})\end{array}$ & $\begin{array}{l}\text { Sand } \\
\text { topdressing } \\
\text { frequency } \\
\text { (no./mo.) }\end{array}$ & $\begin{array}{c}\text { Annual } \\
\text { nitrogen } \\
\text { applied }(\mathrm{lb} / \\
\left.1000 \mathrm{ft}^{2}\right)^{\mathrm{y}}\end{array}$ \\
\hline $\begin{array}{l}\text { Barton Hills } \\
\text { Country Club } \\
\text { (Ann Arbor, } \\
\text { MI) }\end{array}$ & $70: 30$ & 98 & 2 or 3 & 2.5 \\
\hline $\begin{array}{l}\text { Franklin Hills } \\
\text { Country Club } \\
\text { (Franklin, MI) }\end{array}$ & $60: 40$ & 90 & 2 & 2.7 \\
\hline $\begin{array}{l}\text { Meadowbrook } \\
\text { Country Club } \\
\text { (Northville, } \\
\text { MI) }\end{array}$ & $95: 5$ & 95 & 2 or 3 & 4.2 \\
\hline $\begin{array}{l}\text { Red Run Golf } \\
\text { Club (Royal } \\
\text { Oak, MI) }\end{array}$ & $80: 20$ & 100 & 2 & 5.0 \\
\hline
\end{tabular}

${ }^{\mathrm{z} I n f o r m a t i o n ~ p r o v i d e d ~ b y ~ p e r s o n a l ~ c o m m u n i c a t i o n ~ w i t h ~ g o l f ~ c o u r s e ~ s u p e r i n t e n d e n t s ~ M . ~ E d g e r t o n, ~ B . ~}$ Schweihofer, C. Seaborg, and G. Thommes.

${ }^{\mathrm{y}} 1 \mathrm{lb} / 1000 \mathrm{ft}^{2}=48.8243 \mathrm{~kg} \cdot \mathrm{ha}^{-1}$.

Table 2. Different silt and clay percentages present in the sample of golf course putting greens used in the study to determine annual bluegrass emergence at various soil removal depths and sites in 2016, East Lansing, MI.

\begin{tabular}{lcccc}
\hline & BH $^{\mathbf{y}}$ & FH & MB & RR \\
\cline { 2 - 5 } Soil removal depth (inches) ${ }^{\mathbf{z}}$ & & \multicolumn{2}{c}{ Silt and clay (\%) } & \\
\hline 0.5 & 7.1 & 5.3 & 4.9 & 7.0 \\
1.0 & 4.3 & 4.8 & 4.8 & 8.0 \\
1.5 & 5.5 & 4.7 & 4.7 & 5.8 \\
2.0 & 25.4 & 4.6 & 5.1 & 3.7 \\
3.0 & 30.5 & 4.6 & 7.7 & 2.7 \\
\hline
\end{tabular}

${ }^{\mathrm{z}}$ Soil removal depth treatments were accomplished using a core-slicing apparatus (Soil and Plant Nutrient Laboratory, Michigan State University, East Lansing, MI). 1 inch $=2.54 \mathrm{~cm}$.

${ }^{y}$ The study sites were golf courses located in southeastern Michigan: $\mathrm{BH}=$ Barton Hills Country Club $(\mathrm{CC}), \mathrm{FH}=$ Franklin Hills CC, $\mathrm{MB}=$ Meadow Brook CC, RR = Red Run Golf Club.

${ }^{x}$ Silt and clay particle sizes were measured using the hydrometer method (Soil and Plant Nutrient Laboratory Michigan State University, East Lansing, MI). 
assumptions were checked using normal probability plots and side-by-side box plots, respectively. Because there were substantial differences among data variances of site and season, a heterogeneous variance model was fitted with separate variance estimates for each site within each season. When the interaction effects were found to be statistically significant, the interactions were examined using slicing (simple effect tests) and mean separations among the cell means. When the interactions appeared to be spurious or represented differences in magnitude of the studied effects, marginal means were reported and compared. The second analysis treated individual golf course sites as a random factor and compared the performance of soil removal depth treatments across all individual golf courses, representing the entire population of similar golf courses in the

Table 3. Analysis of variance results for annual bluegrass emergence following soil removal depth treatments $35 \mathrm{~d}$ after placing treatment in potting media in 2015 at East Lansing, MI.

\begin{tabular}{lrr}
\hline Source of variation $^{\mathbf{z}}$ & df & $\boldsymbol{P}>\mathbf{F}^{\mathbf{y}}$ \\
\hline Soil removal depth $($ SR) & 4 & $<0.0001^{*}$ \\
Site $($ S) & 3 & $<0.0001^{*}$ \\
SR $\times$ S & 12 & $0.0031^{*}$ \\
Season $($ SE) & 1 & $0.0006^{*}$ \\
SE $\times$ SR & 4 & $0.0038^{*}$ \\
SE $\times S$ & 3 & $0.0025^{*}$ \\
SE $\times S R \times S$ & 12 & $0.0525^{*}$
\end{tabular}

${ }^{\mathrm{z}}$ The study sites were golf courses located in southeastern Michigan. The study was initiated on 20 Aug. (summer) and replicated 16 Oct. (fall).

${ }^{y}$ Mixed-factor effects analysis of variance model in SAS (version 9.4; SAS Institute, Cary, NC) at ${ }^{*} P \leq 0.05$. Germination was based on the number of plants $/ 0.2$ $\mathrm{ft}^{2}\left(0.0186 \mathrm{~m}^{2}\right)$ state of Michigan. Statistical tests were conducted at the 0.05 level of probability. Mean separations were performed based on Fisher's least significant difference (Ott and Longnecker, 2001).

\section{Results and discussion}

Results of the main effect and interaction tests for seedling emergence (number of plants $/ 0.2 \mathrm{ft}^{2}$ ) at 35 DAP are presented in Table 3 . Because the interactions among soil removal depth, sites (golf course), and seasons were statistically significant, we first examined performance of all depth treatments within individual sites for each season (Table 4). The data suggest that in all sites and seasons, there is at least a numeric trend present of lower annual bluegrass emergence at greater depths, with statistically significant differences between the 0.5- and 3-inch depths in a couple sites. For instance, at the 0.5-inch depth in the summer season, Barton Hills CC and Red Run GC had mean plant counts of 11 and 6 plants $/ 0.2 \mathrm{ft}^{2}$, respectively; but as depth increased to 3.0 inches, both sites had no presence of annual bluegrass seedling emergence. Similarly, in the fall season, Barton Hills CC, Red Run GC, and Meadowbrook CC had mean plant counts of 94.3, 17.7, and 10.3 plants $/ 0.2 \mathrm{ft}^{2}$, respectively; and 0.3 or less annual bluegrass plants $/ 0.2 \mathrm{ft}^{2}$ at the 3.0-inch depth. This effect of soil removal depth $\times$ site $\times$ season could be described as an interaction of magnitude.

Significant two-way interactions such as soil removal depth $\times$ season and soil removal depth $x$ site were observed and could also be described as interactions of magnitude with consistent trends of greater seedling emergence in the upper soil profile at all sites for both seasons. Thus, it is prudent to examine main effects of soil removal depth and compare marginal effects of depth treatments (Table 5). Time of sampling may affect annual bluegrass emergence. The soil removal depth $\times$ season interaction results suggest that seedling emergence in the upper soil profile was greatest in October compared with the same treatment in August. This comparison was conducted while treating golf course site as a random effect, thus expanding the applicability of the findings to a broad range of similar golf courses. However, the high variability in emerged seedlings among the sites could be a result of the varying topdressing regimes practiced by each golf course (Table 2). Barton Hills CC had less sand topdressing compared with the other sites, and thus did not bury annual bluegrass seed within the putting green root zone, leaving more seed in their respective uppermost soil depths.

Seasonal temperature fluctuation may have affected annual bluegrass emergence in August and October. R.N. Calhoun (personal communication) suggested that the greatest germination rates occurred at soil temperatures between 54 and 72 ${ }^{\circ} \mathrm{F}-74 \%$ and $73 \%$, respectively-but only $26 \%$ and $19 \%$ germinated, respectively, at $72{ }^{\circ} \mathrm{F}$ and greater. Calhoun (2010) also observed that $100 \%$ of seed germination was between 51 to $75^{\circ} \mathrm{F}$, but none germinated when soil temperatures were less than $51^{\circ} \mathrm{F}$. Wu et al. (1987) also noticed that seed stored between 54 and $77^{\circ} \mathrm{F}$ temperature fluctuations showed a greater

Table 4. Effect of season $\times$ soil removal depth $\times$ site (golf course) on annual bluegrass emergence $35 \mathrm{~d}$ after placing treatment in potting media in 2015 at East Lansing, MI.

\begin{tabular}{|c|c|c|c|c|c|c|c|c|}
\hline \multirow{3}{*}{$\begin{array}{l}\text { Soil } \\
\text { removal } \\
\text { depth (inches) }\end{array}$} & \multicolumn{4}{|c|}{ Summer ${ }^{\mathrm{y}}$} & \multicolumn{4}{|c|}{ Fall } \\
\hline & $\mathrm{BH}$ & FH & MB & RR & $\mathrm{BH}$ & FH & MB & RR \\
\hline & \multicolumn{8}{|c|}{ Mean plants (no. $\left./ 0.2 \mathrm{ft}^{2}\right)^{\mathrm{x}}$} \\
\hline 1.0 & $24.7 \mathrm{bc}$ & $0.3 \mathrm{de}$ & $1.7 \mathrm{cde}$ & $6.0 \mathrm{bcd}$ & $47.3 \mathrm{~b}$ & $0 \mathrm{e}$ & $1.3 \mathrm{cde}$ & 2.7 cde \\
\hline 1.5 & 2.0 cde & $0.3 \mathrm{de}$ & $1.0 \mathrm{cde}$ & $0.7 \mathrm{cde}$ & $34.3 \mathrm{bc}$ & $0 \mathrm{e}$ & $1.3 \mathrm{cde}$ & $2.0 \mathrm{cde}$ \\
\hline 2.0 & $1.3 \mathrm{cde}$ & 1.0 cde & $0 \mathrm{e}$ & $0 \mathrm{e}$ & 3.0 bcde & $0 \mathrm{e}$ & 2.7 cde & 0.7 cde \\
\hline
\end{tabular}

${ }^{\mathrm{z}}$ Soil removal depth treatments were accomplished using a core-slicing apparatus (Soil and Plant Nutrient Laboratory, Michigan State University, East Lansing, MI). I inch = $2.54 \mathrm{~cm}$.

${ }^{{ }}$The study was initiated on 20 Aug. (summer) and replicated 16 Oct. (fall). Sites were golf courses located in southeastern Michigan: BH = Barton Hills Country Club (CC), $\mathrm{FH}=$ Franklin Hills CC, $\mathrm{MB}=$ Meadow Brook CC, $\mathrm{RR}=$ Red Run Golf Club

${ }^{\mathrm{x}} \mathrm{l}$ plant $/ 0.2 \mathrm{ft}^{2}\left(0.0186 \mathrm{~m}^{2}\right)=53.8196$ plants $/ \mathrm{m}^{2}$.

${ }^{\text {w}}$ Mean values are separated in accordance with Fisher's protected least significant difference at $P \leq 0.05$. 
percentage of seed germination compared with storage at a constant temperature. Annual bluegrass emergence also observed to be greatest in spring and autumn, rather than summer (Branham, 1991; Kaminski and Dernoeden, 2007; Shem-Tov and Fennimore, 2003). Similarly, Beard et al. (1978), Engel (1967), and Hovin (1957) noted that temperature fluctuation $\left(50\right.$ to $70{ }^{\circ} \mathrm{F}$ ) promoted the annual bluegrass germination rate, and that consistency of air temperature-either high or low-halted seed germination.

Significant differences were observed among soil removal depth treatments (Table 6). The 0.5-inch soil removal depth had the greatest presence of annual bluegrass seed than all other soil removal treatments. Minimal emergence $(<1.1$ plants $/ 0.2$ $\mathrm{ft}^{2}$ ) was observed at less than the 2.0inch soil removal depth.

\section{Recommendations}

Competition between annual bluegrass and a desirable grass species in creeping bentgrass greens was

is a major concern because they vie for valuable resources such as water, nutrients, and light. Therefore, some degree of soil removal may be necessary when considering a putting green renovation. Research data suggest a conservative soil excavation, at least a 1.0-inch depth or, more prudently, a 1.5- to 2.0-inch depth, may provide golf course superintendents the greatest results with regard to minimum annual bluegrass emergence after renovation. Results also suggest the critical need to remove the upper soil layer if superintendents plan seeding operations in autumn, more so than summer, because temperature seems to be a factor in seedling emergence. Perhaps to get a better understanding of the variability in seedling emergence among sites, a study could be conducted in which multiple greens at an individual site be tested for variation. However, it has been determined that annual bluegrass growing in putting greens is a distinct population to that of grass growing elsewhere. Therefore, regardless of golf course sites, the

Table 5. Effect of season $\times$ soil removal depth on annual bluegrass emergence 35 $\mathrm{d}$ after placing treatments in potting media in 2015 at East Lansing, MI.

\begin{tabular}{llc}
\hline & \multicolumn{1}{c}{ Summer $^{\mathrm{y}}$} & Fall \\
\cline { 2 - 3 } Soil removal depth (inches) $^{\mathrm{z}}$ & $7.1 \mathrm{bc}^{\mathrm{w}}$ & $31.5 \mathrm{a}$ \\
0.5 & $8.2 \mathrm{bc}$ & $12.8 \mathrm{~b}$ \\
1.0 & $1.0 \mathrm{~cd}$ & $9.4 \mathrm{bc}$ \\
1.5 & $0.6 \mathrm{~cd}$ & $1.6 \mathrm{bcd}$ \\
2.0 & $0.1 \mathrm{~d}$ & $0.3 \mathrm{~cd}$ \\
3.0 & (no. $\left./ 0.2 \mathbf{f t}^{2}\right)^{\mathrm{x}}$ \\
\hline
\end{tabular}

${ }^{\mathrm{z}}$ Soil removal depth treatments were accomplished using a core-slicing apparatus (Soil and Plant Nutrient Laboratory, Michigan State University, East Lansing, MI). 1 inch $=2.54 \mathrm{~cm}$.

${ }^{{ }^{2}}$ The study was initiated on 20 Aug. (summer) and replicated 16 Oct. (fall). Sites were golf courses located in southeastern Michigan: Barton Hills Country Club (CC), Franklin Hills CC, Meadow Brook CC, and Red Run Golf Club.

${ }^{\mathrm{x}} 1$ plant $/ 0.2 \mathrm{ft}^{2}\left(0.0186 \mathrm{~m}^{2}\right)=53.8196$ plants $/ \mathrm{m}^{2}$.

wean values are separated in accordance to Fisher's protected least significant difference at $P \leq 0.05$.

Table 6. Effect of soil removal depth on annual bluegrass emergence $35 \mathrm{~d}$ after placing treatments in potting media in 2015 at East Lansing, MI.

\begin{tabular}{lc}
\hline Soil removal depth (inches) $)^{\mathrm{z}}$ & Mean plants $\left(\mathbf{n o .} / \mathbf{0 . 2} \mathbf{f t}^{\mathbf{2}}\right)^{\mathrm{y}}$ \\
\hline 0.5 & $19.3 \mathrm{a}^{\mathrm{x}}$ \\
1.0 & $10.5 \mathrm{~b}$ \\
1.5 & $5.2 \mathrm{bc}$ \\
2.0 & $1.1 \mathrm{c}$ \\
3.0 & $0.2 \mathrm{c}$ \\
LSD & 8.4 \\
\hline
\end{tabular}

${ }^{\mathrm{z}}$ Soil removal depth treatments were accomplished using a core-slicing apparatus (Soil and Plant Nutrient Laboratory, Michigan State University, East Lansing, MI). The study was initiated on 20 Aug. (summer) and replicated 16 Oct. (fall). Sites were golf courses located in southeastern Michigan: Barton Hills Country club (CC), Franklin Hills CC, Meadow Brook CC, and Red Run Golf Club. 1 inch $=2.54 \mathrm{~cm}$.

${ }^{y} 1$ plant $/ 0.2 \mathrm{ft}^{2}\left(0.0186 \mathrm{~m}^{2}\right)=53.8196$ plants $/ \mathrm{m}^{2}$

${ }^{x}$ Mean values separated in accordance with Fisher's protected least significant difference at $P \leq 0.05$

$\mathrm{LSD}=$ least significant difference. greens were colonized by an annual bluegrass population most adaptive to a putting green environment (Sweeney and Danneberger, 1995, 1997). Current research is delving into a method of scarifying the soil, more aptly known as fraise/fraze mowing (Minnick, 2018), to determine the effectiveness of this procedure to control seedling emergence at various soil depths with and without a fumigant (Dazomet, Basamid; Amvac, Lincoln University, PA). Therefore, practitioners might consider these renovation suggestions to minimize plant competition when establishing a creeping bentgrass putting green.

\section{Literature cited}

Barkworth, M.E., K.M. Capels, S. Long, and M.B. Piep. 2003. Flora of North America: North of Mexico, Vol. 25, Magnoliophyta: Commelinidae (in part): Poaceae, part 2. Oxford University Press, New York, NY.

Beard, J.B., P.E. Rieke, A.J. Turgeon, and J.M. Vargas, Jr. 1978. Annual bluegrass (Poa annua L.): Description, adaption, culture, and control. Agr. Expt. Sta. Res. Rpt., Michigan State Univ., East Lansing, MI.

Branham, B.E. 1991. Dealing with Poa annua: Understanding the strength and weaknesses of annual bluegrass is the first step in developing a successful management program. Golf Course $\mathrm{Mgt}$. 59(9):46-60.

Branham, B.E., G.A. Hardbeck, J.W. Meyer, and Z.J. Reicher. 2004. Turfgrass renovation using Dazomet to control the Poa annua L. soil seed bank. HortScience 39:1763-1767.

Calhoun, R.N. 2010. Growing degree days as a method to characterize germination, flower pattern, and chemical flower suppression of a mature annual bluegrass [Poa annua var reptans (Hauskins) Timm ] fairway in Michigan. Michigan State University, East Lansing, MI, PhD Diss.

Ellis, W.M., B.T.O. Lee, and D.M. Calder. 1971. A biometric analysis of populations of Poa annua L. Evolution 25:29-37.

Engel, R.E. 1967. Temperatures required for annual bluegrass and colonial bentgrass. Golf Course Superintendent 35(9):20-23.

Foy, J. and L. Gilhuly. 2015. Time to rebuild the greens or is it? Many factors must be considered before undertaking 
a putting green reconstruction project. USGA Green Sect. Rec. 53(19):1-9.

Gibeault, V.A. and N.R. Goetze. 1973. Annual meadowgrass. J. Sports Turf Res. Inst. 48:9-19.

Gilhuly, L. 2016. A light at the end of the tunnel? U.S. Golf Association, Far Hills, NJ.

Hoagland, D.R. and D.I. Arnon. 1950. The water-culture method for growing plants without soil. California Agr. Expt. Sta. Bul. 347.

Hovin, A.W. 1957. Germination of annual bluegrass seed. Southern California Turf Cult. 7(2):13.

Huff, D.R. 1999. For richer, for Poa: Cultivar development of greens-type $\mathrm{Poa}$ annua. USGA Green Sect. Rec. 37(1):11-14.

Hurdzan, M.J. 2004. Golf greens: History, design, and construction. Wiley, Hoboken, NJ.

Jones, S. 2017. Less turf + better turf $=$ better golf: In an effort to make golf better for the budget and better for the golfer, courses take a close look at where the green goes. Golfdom 73(9):16-18, 22, 24

Jones, P. 2019. Parting shots. Futurama. Golf Course Ind. 51(1):82.

Kaminski, J.E. and P.H. Dernoeden. 2007. Seasonal Poa annua L. seedling emergence patterns in Maryland. Crop Sci. 47:775-781.

La Mantia, J.M. and D.R. Huff. 2011. Instability of the greens-type phenotype of Poa annua L. Crop Sci. 51:17841792.

Law, R. 1981. The dynamics of colonizing population of Poa annua. Ecology 62:1267-1277.

McCarty, L.B., M.F. Gregg, J.E. Toler, J.J. Camberato, and H.S. Hill. 2005. Minimizing thatch and mat in a newly seeded creeping bentgrass golf green. Crop Sci. 45:1529-1535.

Merewitz, E.B., T. Gianfagna, and B. Huang. 2011. Photosynthesis, water use, and root viability under water stress as affected by expression of SAG12-ipt controlling cytokinin synthesis in Agrostis stolonifera. J. Expt. Bot. 62:383-395.

Minnick, J. 2018. 5 Years of fraze mowing evolution. SportsTurf 34(3):18-21.

Ott, R.M. and M. Longnecker. 2001. An introduction to statistical methods and data analysis. 5th ed. Duxbury, Pacific Grove, CA.

Peachey, R.E., J.N. Pinkerton, K.L. Ivors, M.L. Miller, and L.W. Moore. 2001. Effects of soil solarization, cover crops, and Metham on field emergence and survival of buried annual bluegrass (Poa annua) seed. Weed Technol. 15:81-88.

Shem-Tov, S. and S.A. Fennimore. 2003. Seasonal changes in annual bluegrass ( $P o a$ annua) germinability and emergence. Weed Sci. 51:690-695.

Skorulski, J., J. Henderson, and N. Miller. 2010. Topdressing fairways: More is better. USGA Green Sect. Rec. 48(2):15-17.

Sweeney, P.K. and T.K. Danneberger. 1995. RAPD characterization of Poa annua L. populations in golf course greens and fairways. Crop Sci. 35:16761680 .
Sweeney, P.K. and T.K. Danneberger. 1997. Annual bluegrass segregation on greens and fairways. Golf Course Mgt. 65(4):49-52.

Timm, G. 1965. Biology and systematics of Poa annua. Zeitschrift Acker Pflanzenbau 122:267-294.

Tutin, T.G. 1957. A contribution to the experimental taxonomy of Poa annua L. Watsonia 4:1-10.

Vargas, J.M., Jr. and A.J. Turgeon. 2004. Poa annua: Physiology, culture, and control of annual bluegrass. Wiley, Hoboken, NJ.

Warwick, S.I. 1979. The biology of Canadian weeds: 37. Poa annua L. Can. J. Plant Sci. 59:1053-1066.

Wells, G.J. 1974. The biology of Poa annua and its significance in grassland. Herb. Abstr. 44:385-391.

White, B. 2006. Rebuild or resurface: Greens must be rebuilt every 15 to 20 years, even those of USGA method construction-or do they? USGA Green Sect. Rec. 44(1):1-6.

Whitlark, B. and N. Hummel. 2018. Rootzone compatibility testing for putting green resurfacing, expansion, and recontouring. USGA Green Sect. Rec. 56(23):1-8.

Wu, L., I. Till-Bottraud, and A. Torres. 1987. Genetic differentiation in temperature-enforced seed dormancy among golf course populations of Poa annua L. New Phytol. 107:623-631.

Youngner, V.G. 1959. Ecological studies on Poa annua in turfgrasses. J. Brit. Grassl. Soc. 14:233-247. 